\title{
Öğretmen Adaylarının Tarihi Görselleri Analiz Düzeyleri
}

\section{Teacher Candidates' Analysis Levels of Historical Images}

\author{
İbrahim TURAN ${ }^{*}$ \\ Hasan ASLAN* \\ “...tarihi anlamak istiyorsanız portreleri yakından incelemelisiniz. Okumasını \\ bilen için insanların yüzlerinde yaşadıkları dönemin tarihine ait pek çok bilgi \\ vardır" Giovanni Morelli (Akt. Burke, 2001).
}

Öz: Görsel kaynaklar tarih araştırmalarında ve öğretiminde büyük bir öneme sahiptir. Tarih eğitiminde görsel kaynaklar doğası gereği soyut olan tarihi bilgiyi somutlaştırarak onu yeni kuşaklar için daha anlaşılır bir hale getirmekte aynı zamanda öğrencilerin yaratıcı düşünce ve hayal gücünün gelişmesinde yardımcı olmaktadır (Smirnova ve Romanov, 2007: 1). Öğrencilerin görsel analiz becerilerini geliştirmek sadece tarih derslerindeki kavrama ve başarı düzeyleri açısından değil aynı zamanda yaşam boyu öğrenme becerilerinin gelişimi açısından da önemlidir. Çünkü bu alanda iyi olan bir kişi, çevresinde gördüğü eylemlerin, objelerin ve sembollerin farklıığını anlayabilmekte ve onları daha doğru yorumlayabilmektedir (Alpan, 2008: 76-77). Öğrencilerin görsel analiz becerilerinin gelişiminde en önemli unsur tabi öğretmenlerdir. Görsellerin öğretmenler tarafından tarih derslerinde doğru kullanımı öğrencilerin görsel analiz ve görsel okuryazarlık becerilerini olumlu yönde etkileyecektir.

$\mathrm{Bu}$ araştırmanın amacı tarih ve sosyal bilgiler öğretmen adaylarının görsel analiz düzeylerini tespit etmektir. Çalışmada nitel durum araştırması yöntemi ve iç içe geçmiş tek durum deseni kullanıımıştır. Çalışma grubuna Atatürk Üniversitesi Kazım Karabekir Eğitim Fakültesi Tarih Eğitimi ve Sosyal Bilgiler Eğitimi son sınıf öğrencileri dâhil edilmiştir. Veri toplama aracı olarak araştırmacılar tarafından hazırlanmış "Görsel Analiz Düzeyi" çalışma kâğıdı kullanıımıştır. Araştırma sonucunda öğretmen adaylarının büyük çoğunluğunun tarihsel görselleri analiz ederken tanımlama düzeyindeki görevlerde dahi zorlandıkları, görseller hakkında derinlemesine ve detaylı analizler yapamadıkları, genellikle kısa ifadeler ve açıklamalar kullandıkları, akademik bir tavır sergileyemeyerek kaynağa duygusal bir bakış açısı ile tarafı ı bir şekilde yaklaştıkları dolayısıyla sergiledikleri görsel analiz becerilerinin aldıkları eğitime kıyasla yeterli olmadığı belirlenmiştir.

\footnotetext{
* İstanbul Üniversitesi, HAYEF, Sosyal Bilgiler Eğitimi ABD, E-posta: ibrahim.turan@istanbul.edu.tr

** Atatürk Üniversitesi, KKEF, Tarih Eğitimi ABD, E-posta: hasan.aslan@atauni.edu.tr
} 


\author{
Anahtar Kelimeler: Tarihi Görseller, Görsel Analiz, Görsel Okuryazarlık, Görsel \\ Yorumlama
}

\begin{abstract}
Visual resources has a great importance in historical research and teaching. Visual resources makes historical knowledge, which is abstract by nature, more understandable for new generations by making it concrete at the same time help students develop creative thinking and imagination (Smirnova ve Romanov, 2007: 1). Helping students develop visual analysis skills is necessary not only in terms of comprehension and achievement levels, but also important for the development of lifelong learning skills. A person who is good in visual analysis can easily understand the diversity of actions, objects and symbols he/she witnesses in daily life and interpret them more correctly (Alpan, 2008: 76-77). The most important element in the development of visual analysis skills of students are the teachers. The proper usage of the visuals in history lessons by teachers will have a positive impact on students' visual analysis and visual literacy skills.

The aim of this research is to determine History and Social Studies teacher candidates' level of visual analysis skills. An embedded single-case design was used in this qualitative case study. The senior students from two departments, History Education and Social Studies Education, at Atatürk University, Kazım Karabekir Education Faculty were set as study population for his research. Required data for this study were gathered by "visual analysis level worksheet" prepared by the researchers. The results show that while analyzing historical images the majority of teacher candidates had hard time seven at identification level tasks, unable to perform in-depth and detailed analysis, use short phrases and explanations, approach resources with an non-academic, emotional and biased perspective therefor their analysis skills are inadequate compared to their level of education.
\end{abstract}

Keywords: Historical Images, Visual Analysis, Visual Literacy, Visual Interpretation

\title{
Giriş
}

Resim yoluyla bilgi aktarımı yani iletişim insanlığın yazının keşfinden çok önce kullanmaya başladığı bir yöntemdir. Bu nedenle görsel kaynakların analizi eski çağları araştıran antropolog ve arkeologlar için önemli bir veri toplama aracıdır. Yazının keşfinden sonraki dönemi araştıran tarihçiler için - özellikle kâğıdın ve matbaanın keşfinden sonra- yazılı belgelerin görsel belgelerden daha önemli hale geldiğini görmekteyiz (Howels ve Matson, 2009: 1). Bu nedenle 19. Yüzyıl başlarında ortaya çıkan belgeye dayalı tarihyazım olarak özetlenebilecek "modern tarih" için geliştirilen metodolojide tarihi belgelerin otantikliğini ve güvenirliğini değerlendirmek amacıyla uygulanan yöntemler daha ziyade yazılı belgelerin analizine yöneliktir. Resim, tablo ve çizimlerin dokunulmamış, üzerinde oynama yapılmamış, birebir gerçeği yansıtma konusundaki zayıflıkları modern tarihçilerin görsel kaynakları kullanma konusunda çekimser davranmasına yol açmıştır. Ancak fotoğraf makinesinin icadı bu alandaki ön yargıları kırmıştır. 19. yy.'ın ilk yarısında ilk fotoğrafların basılması ile tarihçiler için yeni 
bir veri kaynağı, tarih eğitimcileri içinse yeni bir öğretim materyali ortaya çıkmıştır. Mitchell'e (1994) göre bu değişim yüzyıllardır süren yazı-temelli iletişim safhasının sonunu işaret ediyordu. Yine de diğer disiplinlerle karşılaştırıldığında tarihçiler görsel safhaya geçişte daha yavaş ve temkinli davranmışlardır (Coventry v.d., 2006).

Sosyal tarih ekolü yaygınlaşana kadar klasik tarihçilerin bir kanıt olarak görselleri yeterince ciddiye almadıklarını belirtmek gerekir. Günümüzde dahi matbu ve el-yazma arşivlerde araştırma yapan tarihçi sayısı görsel arşivlerde çalışan tarihçilerden daha fazladır. Akademik tarih dergilerinde yayınlanan makalelerde kullanılan görsel sayısı da aynı nispette azdır. Yayınlarında görsele yer veren tarihçiler bile çoğu zaman bunları bir çıkış noktası olarak kullanmaktan ziyade yazıda ulaştıkları sonuçları resmetmek (illüstrasyon) veya görselle desteklemek amacıyla kullanmaktadırlar (Şimşek, 2014; Burke, 2001: 10).

19. ve 20. yy.'da kullanılan tarih ders kitapları büyük oranda yazı ağılıklı iken günümüzde basılan ders kitaplarında fotoğraf, harita, minyatür, çizim, tablo, portre gibi çok farklı görsel kullanılmakta ve yazı-görsel oranı görsel lehine hızla artmaktadır. Ancak görsellerin destekleyici yani yazıda anlatılanı açıklayıcı rolünün değiştiğini söylemek mümkün değildir (Howels ve Matson, 2009: 2). Akademik tarihçilerin yaptığı gibi ders kitabı yazarları da görselleri yazıda anlattıkları hikâyeleri resmetmek amacıyla kullanmaktadır. Bu kitapları derslerinde kullanan tarih öğretmenleri ise kitaplarda yer alan görselleri incelemek yerine yazıya odaklanmaktadır (Pegler-Gordon, 2006). Öğretmenlerin bu davranışlarında ders kitaplarında görsellerin yukarıda bahsedilen kullanım amacının ve üniversitelerde hâkim olan geleneksel yazı-temelli tarih öğretiminin etkisi büyüktür.

İletişimde fotoğrafla başlayan görsel safha sinema ve televizyon ile devam etmiş ve son olarak kişisel bilgisayar, internet, tablet ve cep telefonları ile gündelik hayatın vazgeçilmez bir parçası haline gelmiştir. Teknoloji ve sosyal hayatta meydana gelen bu değişim ister istemez tarihçileri araştırma ve öğretim faaliyetlerinde görsellere daha fazla yer vermeye zorlamaktadır (Pegler-Gordon, 2006). Ancak artan bu kullanımın doğru kullanım anlamına geldiği söylenemez. Her ne kadar tarih dersleri ve ders kitaplarında yer alan görsellerin oranı artmaktayken görseller nadiren öğretimde başrol üstlenmektedir. Görseller, görsel analiz konusunda bilgi sahibi olan az sayıda öğretmen tarafından tarihsel yorumlama aracı, farklı bakış açılarını ortaya koyan bilgi 
kaynağı olarak kullanılmakta çoğu tarih dersinde söz ya da yazı temelli sunumu destekleyici bir rol üstlenmektedir (Coventry v.d., 2006).

Literatürde görsel analiz veya görsel yorumlama olarak geçen bu kavram tarihçilerin birinci el kaynak statüsünde olan görselleri kullanarak geçmiş yapbozunu tamamlamak, olayları açıklamak ve geçmiş hakkında bir yorum geliştirmek amacıyla incelemesidir. Wineburgh'e (1991) göre uzman tarihçiler iki tür kaynak incelemesi yaparlar: sorgulayıcı kaynak incelemesi ve doğrulayıcı kaynak incelemesi. Sorgulayıcı kaynak incelemesinden kasıt geçmiş hakkında bir argüman geliştirmek amacıyla belgenin güvenirliğini, yazarın kimliğini, niyetini ve olayla alakasını sorgulamaktır. Doğrulayıcı kaynak incelemesi ise belgede yer alan bilgiyi başka belgelerde verilen bilgi ile karşılaştırmaktır.

Burke'ye (2001: 34) göre tarihi görsellerin derinlemesine analizi ve yorumlanması tarih bilgisi dışında sanat tarihi bilgisi ve özellikle imgebilim (iconography) gerektirmektedir. İmgebilimden yoksun, görselin oluşturulduğu dönemin kültürel ve sosyolojik özeliklerini bilmeden yapılacak bir analiz yüzeysel kalacak görselin vermeye çalıştığı asıl mesajı ortaya koyamayacaktır. Bu da gösteriyor ki analizi gerçekleştirenin bilgi düzeyine bağlı olarak bir görsel farklı düzeylerde analiz edilebilir. Ünlü Alman sanat tarihçisi Panofsky (1939: Akt. Burke, 2001: 35-36) bu seviyeleri şöyle belirlemiştir:

a) Ön-ikonografik analiz: Bu seviyede tarihçi görsel üzerindeki objeler (insanlar, binalar, araçlar, ağaçlar, hayvanlar vb.) ile olayları (savaş, yemek, üretim vb.) belirleyerek görselin biçimsel yani görünürdeki anlamını ortaya koyar. Bu seviyede tarihçi değerlendirmesini görselde verilenler üzerinden yapar, konu ile ilgili bilgisini işe koşmaz. Örneğin: "Bu bir savaştan enstantanedir."

b) İkonografik analiz: Bu seviyede tarihçi konu ile ilgili bilgilerini işe koşarak görselde anlatılan olayı, mekânı veya zamanı tanımlayarak görselin geleneksel anlamını ortaya koyar. Örneğin: "Bu Çanakkale Savaşından bir enstantanedir."

c) İkonolojik analiz: Görsel analizde en üst seviye olan ikonografik seviyede tarihçi görselin oluşturulduğu dönemdeki kültürel nitelikler, sanatçının kişiliği belirleyerek görselin içerdiği gerçek anlamı ortaya koymaya çalışır.

Buradan yola çıkarak tarih derslerinde gerçekleştirilecek görsel kaynak incelemesi etkinliğinde uygulanması gereken aşamaları şöyle sıralayabiliriz: 
- Görselin türünü, üretim tarihini ve üretim yerini tanımlamak,

- Sanatçıyı (fotoğraf sanatçısı, ressam, çizer, zanaatkâr vs.) tanımlamak,

- Sanatçının olayla alakasını, niyetini, tarafını tanımlamak,

- Sanatçının veya yayıncının hedef kişi veya kitlesini tanımlamak,

- Görselde verilen olguları, objeleri, olayları tanımlamak,

- Görselde kullanılan simgeleri ve bunların ne anlama geldiğini tanımlamak,

- Görselde verilen gizli ve açık mesajları ortaya koymak,

- Görselde olay, olgu ve mesajlara dair tahminleri için kanıt göstermek,

- Görselde dönemin bakış açısından kaynaklanan unsurları ortaya koymak,

- Görselde verilen bilgileri diğer kaynaklarda verilenlerle karşılaştırmak,

- Görselde daha iyi (doğru) açıklamak için hangi ek bilgi ve kaynaklara ihtiyaç olduğunu ortaya koymak,

- Ve son olarak tüm bunlardan yola çıkarak kaynak ve kaynakta anlatılan olay hakkında bir yorum geliştirmek (Şimşek, 2014; Demircioğlu, 2007; Stradling, 2003; Library of Congress, t.y.).

$\mathrm{Bu}$ aşamalar görseller dışında tarihin diğer kaynakları için de uygulanabilir. Öğrenciler farklı formattaki kaynakları analiz ettiklerinde ve bu analizlerde sergiledikleri davranışları birer alışkanlık haline getirdiklerinde sadece tarih dersinde değil tüm derslerinde ve hatta hayatta daha başarılı olacaklardır (Brown; 2000). Çünkü herhangi bir bilgi kaynağı karşısında gösterilen bu entellektüel ve duygusal yaklaşım eleştirel düşünmenin kalbidir (Levy \& Murnane, 2004).

$\mathrm{Bu}$ alanda yapılan araştırmalar tarih derslerinde farklı formattaki görsel materyallerin tarih derslerinde kullanımının faydalarını şu şekilde ortaya koymaktadır:

- Geçmiş toplumların yazıya aktarılamamış yaşantıları hakkında bilgi verir, yazılı metinlerin eksikliklerini tamamlarlar ve yazılı metinlerde gözden kaçabilecek, sözcüklere dökülmemiş olan ayrıntıları görmemizi sağlar (Burke, 2001).

- Öğrencilerin görsel hafızalarını geliştirir, onların tarihi olayları daha doğru ve daha hızlı bir şekilde tasvir etmelerine olanak sağlar ve unutmalarını güçleştirir (Ata, 2002).

- Öğretimin etkililiğini ve kalıcılığını artırır, öğrenmenin planlanan süreç içerisinde tamamlanması sağlar (Demircioğlu, 2007; Sezer, 2006; İşman, 
2005; Kılıç ve Seven, 2004).

- Görsel materyal kullanılarak sözel ve görsel olarak sunumları yapılan konuların hatırlanması daha kolay olur (Özmen, 2005; Uşun, 2012).

- Soyut kavramların görselleştirilerek somutlaştııımalarını sağlarlar (Uşun, 2012; Demircioğlu, 2007; Özmen, 2005).

- Doğası gereği kırılgan, nev-i şahsına münhasır ve genellikle çelişkili olan birincil kaynakların derslerde kullanılması öğrencilere tarihsel araştırmanın ve tarihte genel geçer bir yoruma varmanın zorluğunu öğretir (Tally ve Goldenberg; 2005: 3).

- Farklı görsellerin veya dokümanla birlikte görsellerin incelenmesine dayalı aktiviteler öğrencilerin geçmişe dair farklı bakış açılarını görmelerini sağlar (Bell-Russel, 2011: 2).

- Görsel kaynakların nasıl analiz edileceğinin öğretilmesi öğrencilerin tarihçilik becerilerini geliştirecektir (Craver, 1999: 8).

- Günümüz öğrencileri büyük oranda görsel öğrenmeyi tercih etmektedir (Oblinger, 2003), dolayısıyla görsel kullanarak yapılacak bir öğretim öğrencilerin öğrenim yöntemi tercihlerine hitap edecektir.

\section{Araştırmanın Amacı}

$\mathrm{Bu}$ araştırmada yukarıda eğitimde kullanım faydaları belirtilmiş olan tarihsel görselleri derslerinde sıklıkla kullanmak durumunda olacak tarih ve sosyal bilgiler öğretmen adaylarının tarihsel görselleri analiz düzeylerinin belirlenmesi amaçlanmıştır.

\section{Yöntem}

\section{Araştırma Modeli}

Araştırmada nitel durum çalışması yöntemi uygulanmıştır. Merriam (1998: 27) nitel durum çalışmalarını "bir örneğin, olgunun veya sosyal birimin, yoğun, bütüncül bir biçimde tanımlanması ve analizi" olarak ifade etmiştir. Araştırma deseni olarak da "iç içe geçmiş tek durum deseni" kullanılmıştır. Bu desen; tek bir durum içinde yer alan farklı boyut veya alt durumların incelenmesi olarak tanımlanabilir (Yin, 2003: 39). 
Araştırmaya konu olan görsel analiz becerileri için üç alt düzey (tanımlama, kavrama ve değerlendirme) belirlenmiş ve öğretmen adaylarının her bir alt düzey doğrultusunda sergiledikleri beceriler değerlendirilmiştir.

\section{Çalışma Grubu}

Araştırmanın çalışma grubuna 2013-2014 eğitim öğretim yılının Bahar döneminde, Atatürk Üniversitesi Kazım Karabekir Eğitim Fakültesi Tarih Eğitimi ve Sosyal Bilgiler Eğitimi son sınıflarına devam eden öğrenciler dâhil edilmiştir. Gönüllülük esasına göre gerçekleştirilen uygulamaya tarih eğitim 5. Sınıf öğrencilerinden 23 ve Sosyal Bilgiler Eğitimi 4. sınıf öğrencilerinden 25 olmak üzere toplam 48 öğretmen adayı katılmıştır.

\section{Veri Toplama Aracı}

Veri toplama aracı olarak araştırmacılar tarafından hazırlanmış "Görsel Analiz Düzeyi” çalışma kâğıdı kullanılmıştır. Bu çalışma kâğıdı tarih derslerinde en sık kullanılan formatlar olan fotoğraf, poster ve minyatür formatında üç görsel ve öğrencileri yönlendirmek için altlarında yer alan 6'şar (toplam 18) ucu açık sorudan oluşmaktadır. Çalışma kâğıdında kullanılan sorular alanda yapılan araştırmalar (Özellikle Şimşek, 2014; Demircioğlu, 2007; Stradling, 2003) ışığında belirlenmiştir.

Literatürde görsel analiz becerileri için farklı alt seviyeler belirlenmiştir. Panofsky (1939: Akt. Burke, 2001: 35-36) görsel analizin a) Ön-ikonografik analiz, b) İkonografik analiz, c) İkonolojik analiz olmak üzere üç seviyesi olduğunu belirlemiştir. Amerikan Kongre Kütüphanesi ise yine görsel analiz altında üç alt seviye belirlemiş ve bunları "Gözlem, Fikir yürütme ve Sorgulama" olarak isimlendirmiştir (Library of Congress, t.y.). Bu araştırmada görsel analiz düzeyi altında üç alt beceri düzeyi belirlenmiştir. Tablo 1'de bu alt düzeyleri ve kapsamlarını, Tablo 2'de ise çalışma kâğıdında kullanılan soruların alt düzeylere göre ayrımını görebilirsiniz. 
Tablo 1

Görsel Analiz Düzeyleri ve Bunların Kapsamları

\begin{tabular}{|c|c|}
\hline Seviye & Kapsam \\
\hline Tanımlama & $\begin{array}{l}\text { Görselin türünü (Resim, poster, karikatür, afiş, fotoğraf, tablo, } \\
\text { gravür, minyatür vs.), sanatçısını, üretim tarihini, görselde } \\
\text { anlatılan zamanı, mekânı, kişileri, kişilerin birbirleriyle } \\
\text { bağlantısını, kıyafetleri, yapıları, eşyaları, coğrafyayı, olay veya } \\
\text { faaliyetin türünü tanımlama veya tahmin etme. }\end{array}$ \\
\hline Kavrama & $\begin{array}{l}\text { - Olay, olgu ve mesajlara dair tahminleri için kanıt gösterme } \\
\text { - Olay / Faaliyetin ne olduğunu ortaya koyma } \\
\text { - Sembolleri tanımlama (gizli-açık) } \\
\text { - Görselin yapılış amacını ortaya koyma } \\
\text { - Görselin hedef kitlesini tanımlama } \\
\text { - Görselde verilen bilgiyi, gizli-açık mesajı ortaya koyma }\end{array}$ \\
\hline Değerlendirme & $\begin{array}{l}\text { - Görseli diğer tarihsel kaynaklarla karşılaştırma } \\
\text { - Görselde verilen bilgi/mesaj güvenirliğini ortaya koyma } \\
\text { - Daha doğru bir değerlendirme için ihtiyaç duyulan kanıtlar / } \\
\text { ilave bilgileri tanımlama. }\end{array}$ \\
\hline
\end{tabular}

Tablo 2

Görsel Analiz Seviyelerine göre Görsel Analiz Düzeyi Çalışma Kâğıdında Yer Alan Sorular

\begin{tabular}{|c|c|}
\hline Seviye & Sorular \\
\hline Tanımlama & $\begin{array}{l}\text { - } \text { Fotoğrafta yer alan kişi ve araçları tanımlayınız. } \\
\text { - Bu insanlar ne yapmaktadır? } \\
\text { - Bu fotoğraflar hangi yıllara ait olabilir? } \\
\text { - Bu fotoğraflar nereye ait olabilir? }\end{array}$ \\
\hline Kavrama & 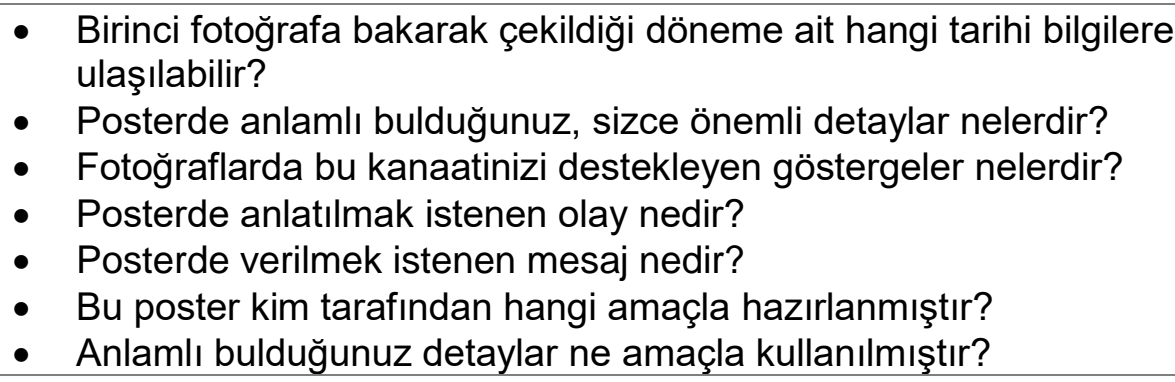 \\
\hline Değerlendirme & $\begin{array}{l}\text { - Görselde verilen mesaj/bilgi dönem/olay hakkındaki bilgilerinizle } \\
\text { ne derece uyuşmaktadır? } \\
\text { - Bu bilgiler/mesajlar ne derece güvenilirdir / doğrudur? } \\
\text { - Bu posteri daha iyi açıklamak için hangi bilgilere ihtiyacınız } \\
\text { vardır? } \\
\text { - Bu görsel tarih derslerinde hangi amaçla kullanılabilir? }\end{array}$ \\
\hline
\end{tabular}


Görsel Analiz Düzeyi çalışma kâğıdında üç ayrı formatta görsel kullanılmıştır. Çalışma kâğıdında ilk olarak Galata Köprüsünün 1920'li ve 2000'li yıllara ait aynı açıdan çekilmiş iki adet fotoğraf kullanılmıştır (Bkz. Şekil 1).

Şekil 1. Çalışma Kâğıdında Yer Alan Galata Köprüsünün 1920'li ve 2000'li Yıllara Ait Aynı Açıdan Çekilmiş Fotoğrafları (Web-1; Web-2)
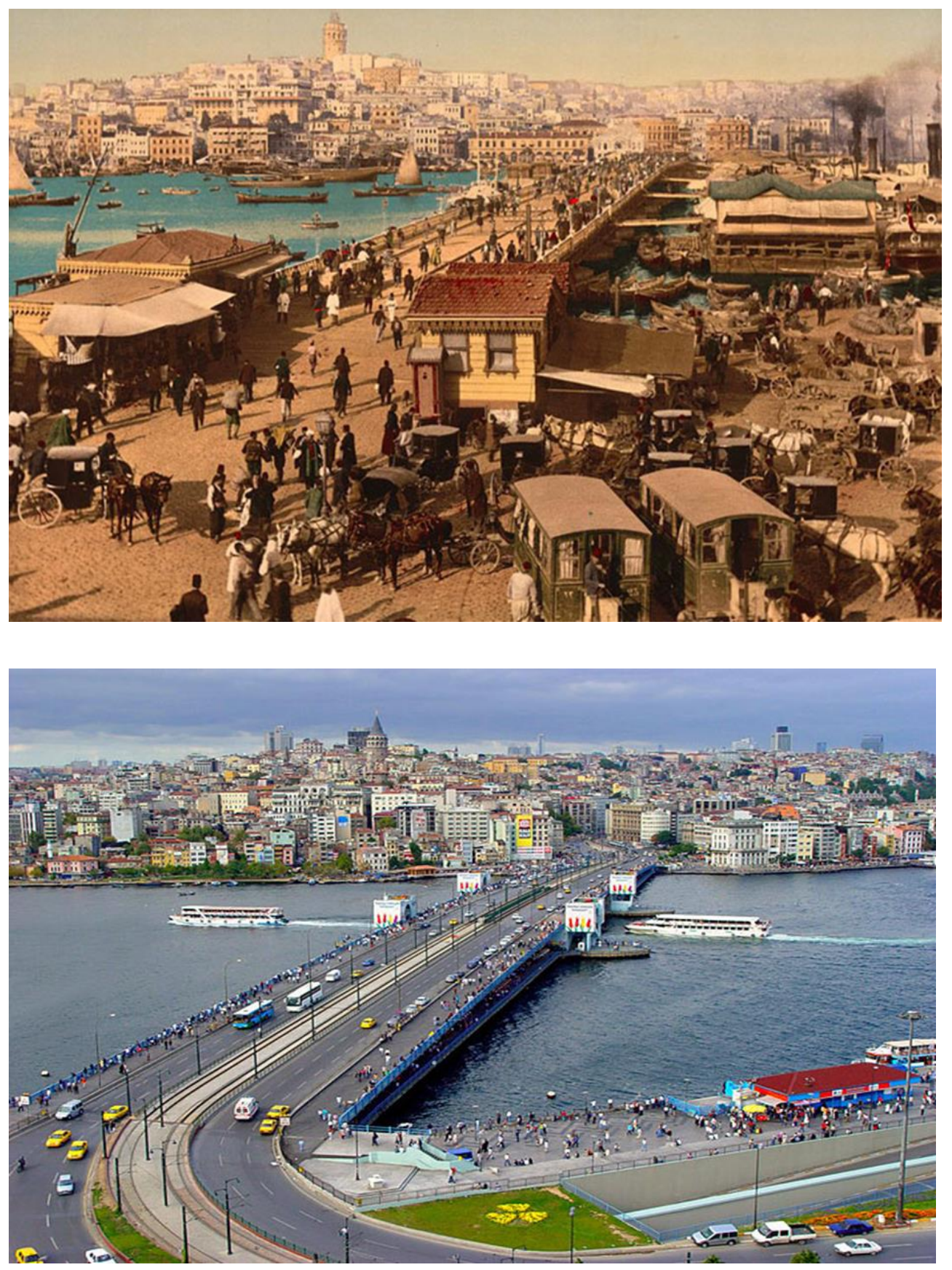
Çalışma kâğıdında yer alan ikinci görsel 1917 yılına ait bir Amerikan savaş posteridir. Poster üzerinde yer alan İngilizce ifadeler Türkçe'ye tercüme edilerek kullanılmıştır (Bkz. Şekil 2).

Şekil 2. Çalışma Kâğıdında Yer Alan Amerikan Savaş Posteri (Web-3)
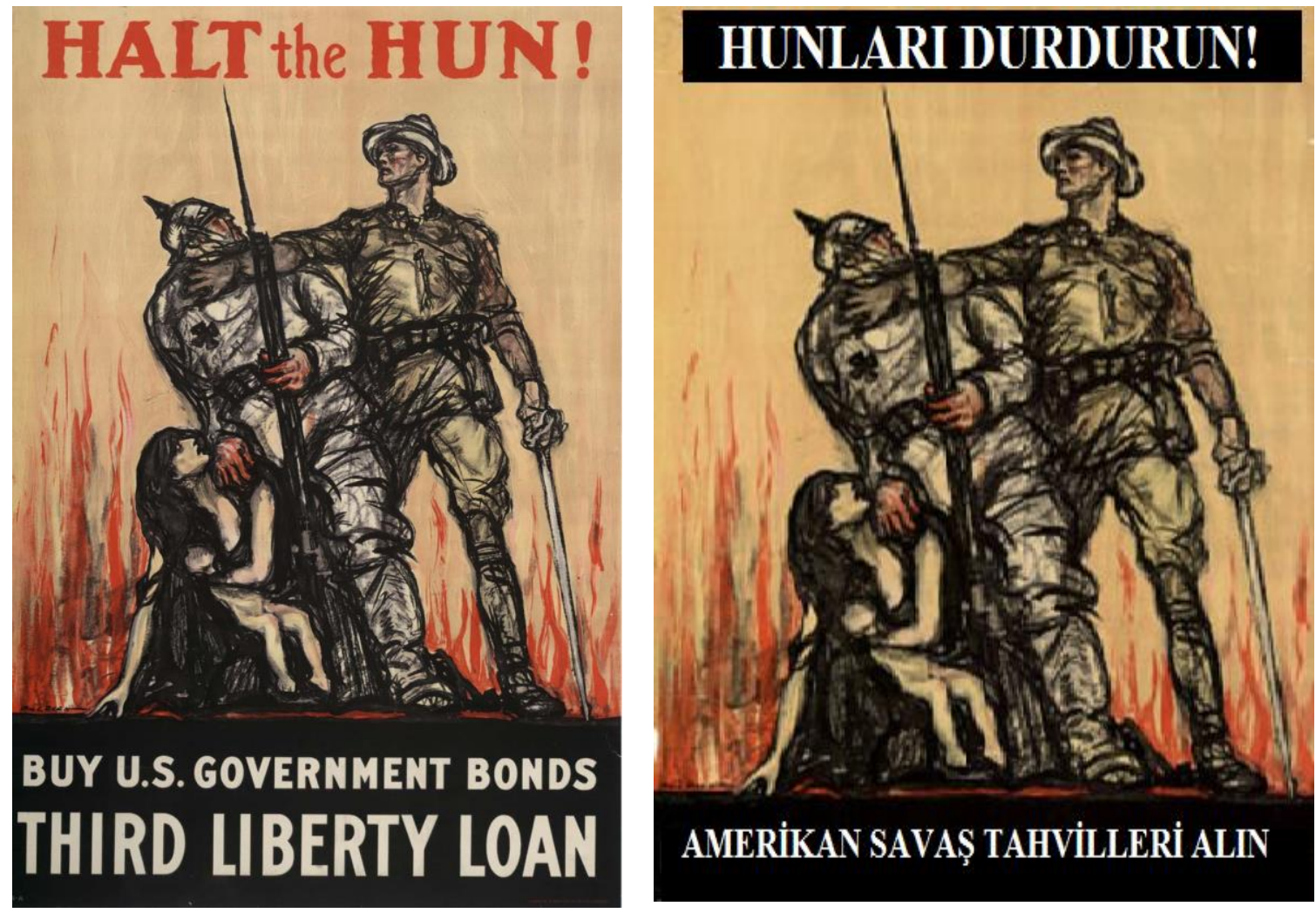

Çalışma kâğıdında yer alan üçüncü görsel ise Nakkaş Osman ve ekibi tarafından çizilen 1588 tarihli İstoni Belgrad Kalesi'nin fethini tasvir eden minyatürdür (Bkz. Şekil 3). 
Şekil 3. Çalışma Kâğıdında Yer Alan Minyatür (Mahir, 2012)

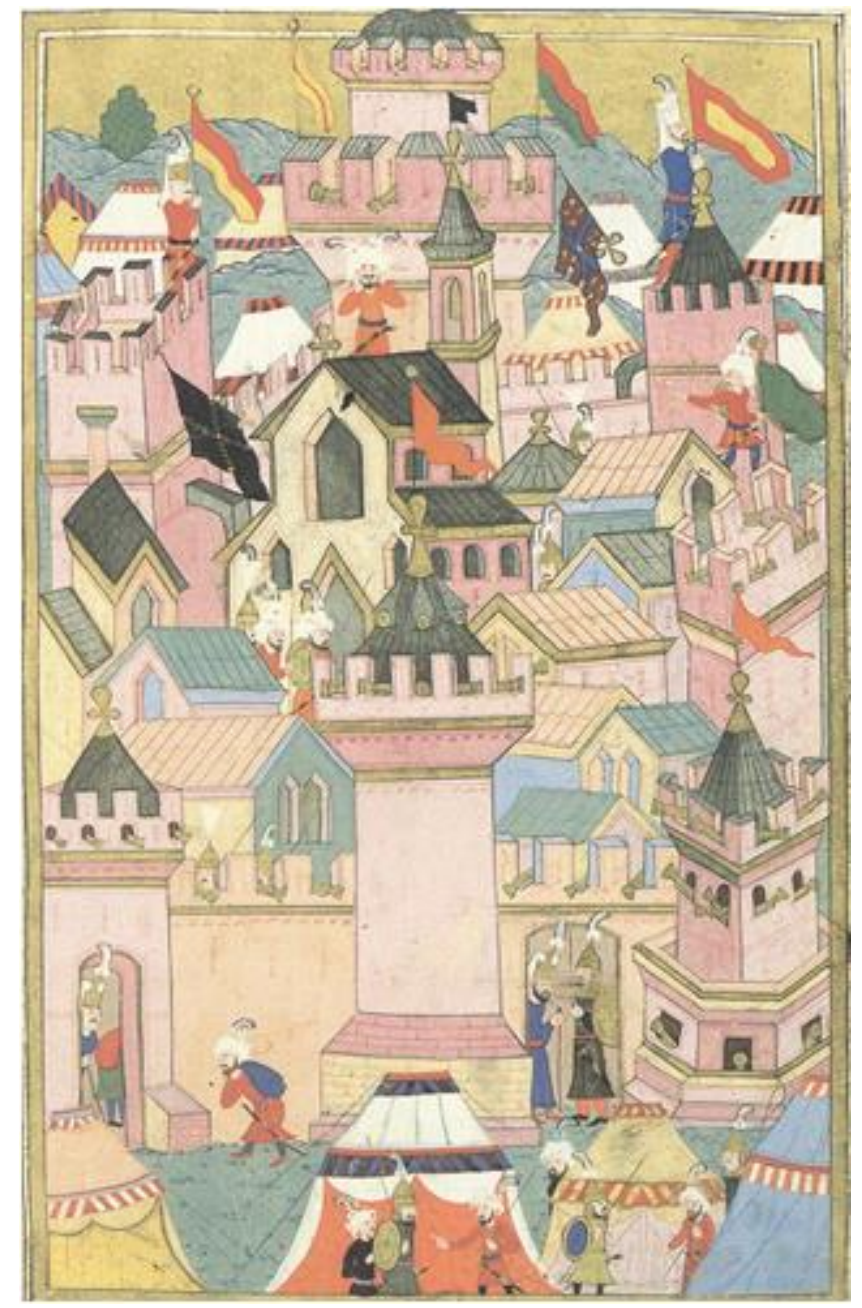

\section{Verilerin Analizi}

Veri toplama aracı olarak kullanılan "Görsel Analiz Düzeyi” çalışma kâğıdıdında yer alan ucu açık sorulardan elde edilen veriler içerik analizine tabi tutularak "birbirine benzeyen veriler belirli kavramlar ve temalar çerçevesinde bir araya getirilmiş, okuyucunun anlayacağı bir biçimde düzenlenerek yorumlanmışırı" (Yıldırım, Şimşek, 2011: 227). İçerik analizi sonucunda ulaşılan bulgular kategoriler halinde tablolaştııımış, oluşturulan tablolarda yakın ve benzer ifadeler aynı kategorilerde birleştirilerek frekans değerleri belirlenmiştir. Öğrenciler sorulara birden çok cevap verebildiği için bazı tablolardaki toplam frekans değeri ile katıımcı öğrenci sayısı arasında fark oluşmuştur. 


\section{Bulgular}

Bu bölümde öğretmen adaylarının görsel analiz düzeylerine dair bulgular Görsel Analiz Düzeyi çalışma kâğıdında yer alan seviyelere (Tanımlama, Kavrama, Değerlendirme) göre tek tek ele alınacaktır.

\section{Tanımlama Düzeyi}

Öğretmen adayları Türkiye coğrafyası ve Türk tarihi ile ilgili görsellerde kişi, araç ve binaları tanımlamada, mekânı ve zamanı tahminde bir sorun yaşamamışlardır. Araştırmada kullanılan fotoğrafların İstanbul'a (Haliç, Galata) ait olduğunu ve bu fotoğraf ve minyatürde yer alan kişileri (hamal, tüccar, padişah, muhafız, yeniçeri vb.), bunların kullandıkları farklı kıyafetleri (Fes, Osmanlı dönemi kıyafetleri vb.), araçları (fayton, at arabası, kayık, buharlı vapur vb.) ve yapıları (Galata Kulesi, Galata Köprüsü vb.) ortaya koymuşlardır.

Ancak görevi biraz zorlaştırdığımızda ve başka bir topluma ait, çeldiriciliği yüksek bir posteri analiz etmelerini istediğimizde bu durum değişmiştir. Posterde iki asker, bir kadın ve bir çocuk yer aldığını belirtmişlerdir. Fakat bu askerlerin hangi ülkenin askeri olduğu konusunda yanılgıya düşmüşlerdir. Bu yanılgı poster üzerinde bulunan yazıyı yanlış yorumlamalarından ve Türk tarihi ile ilgili olmayan kıyafet, silah ve simgeleri tanımamalarından kaynaklanmaktadır.

"Hunları durdurun! Amerikan savaş tahvilleri alın."

Posterdeki yazılı mesajda geçen "Hun" kelimesi katılımcılar için önemli bir çeldirici olmuştur. Katılımcılar bu kelimeden dolayı postere karşı duygusal bir yaklaşım sergilemişler bu nedenle tarafsızlıklarını kaybederek belgeyi eleştirel bir bakış açısıyla değerlendirememişlerdir. Posterde görsel olarak Hunlara veya Türklere yönelik hiçbir atıf bulunmamasına rağmen birçok öğretmen adayı yazılı mesaj ile görsel mesaj arasındaki çelişkiyi fark edemeden sadece yazılı mesajın duygusal etkisinde kalarak kişileri, dolayısıyla zamanı ve olayı yanlış tahmin etmişlerdir. Posterde yer alan "Amerikan Savaş Tahvilleri Alın” ifadesine rağmen tarih eğitimi öğrencilerinden 8'i, sosyal bilgiler eğitimi öğrencilerinden 14'ü ABD'yi posterde anlatılan taraflardan biri olarak göremeyip Amerikan askerini; İngiliz, Alman veya Anzak olarak 
tanımlamışlardır. Yine kıyafetleri Türk askeri kıyafetlerine benzememesine, başında yer alan Alman miğferi ve göğsündeki haç işaretine rağmen tarih eğitimi öğrencilerinden 14'ü, sosyal bilgiler eğitimi öğrencilerinden 12'si Alman askerini Türk, Osmanlı veya Hun olarak tanımlamışlardır.

Tarih ve sosyal bilgiler öğretmen adayları posterde yer alan Alman ve Amerikan askerlerinin I. Dünya Savaşı yıllarında kullandığı silahlar veya kıyafetleri tanımadığından ve yine posterde yer alan yazıyı yanlış yorumladıklarından dolayı posterde anlatılan olayın zamanını büyük oranda yanlış tahmin etmişlerdir. Araştırmaya katılan 23 tarih eğitimi bölümü öğrencisinden sadece 14,25 sosyal bilgiler bölümü öğrencilerinden ise sadece 8'i posterin I. Dünya Savaşı yıllarına ait olduğunu ortaya koyabilmişlerdir. Çeldirici "Hun" kelimesinden dolayı bazı öğrenciler posterdeki zamanı tahminde önemli bir ipucu görevi görebilecek "tüfek"i göz ardı ederek anlatılan olayı Hunlarla bağdaşıırmışlar ve "kavimler göçü, 375, Hunlar dönemi" gibi gerçeğe çok uzak tahminlerde bulunabilmişlerdir.

Minyatür uygulamasında katılımcılardan minyatürde anlatılan olayın türünü tanımlamaları istenmiştir. Tarih eğitimi öğrencileri büyük oranda anlatılan olayın "kale fethi" olduğunu ortaya koymuşlardır. Tarih eğimi öğrencilerinden sadece 5'i "kilisede ezan okunması" ile fethin tamamlandığının simgelendiğini göremediğinden olayı "fetih hazırıkları" olarak tanımlamışlardır. Sosyal bilgiler eğitimi öğrencilerinden ise sadece bir tanesi minyatürde anlatılan olayı doğru tanımlamıştır. Diğerleri konu ile ilgili alan bilgilerinin azlığından ve eğitim gördükleri alanın etkisinden dolayı anlatılan olay için daha sosyal tanımlar yapmışlardır: "Iş̧birliğinin önemi, Çalışmak, Hoşgörü, Insan ilişkileri, Günlük hayattaki olaylar" gibi.

\section{Kavrama Düzeyi}

Bu düzey altında ilk olarak katılımcıların görsele dair verdikleri tahminler, fikir yürütmeler için kanıt gösterme becerileri incelenmiştir. Yargılar için kanıt gösterme, eleştirel düşünmenin en önemli göstergelerindendir ve her insanın sahip olması gerekin bir beceridir. Fotoğrafların hangi yıla ait olduğuna dair tahminleri için görselde yer alan kanıtları ortaya koymaları istendiğinde tarih eğitim öğrencilerinin tamamı "giyim-kuşam, ulaşım araçları ve mimari yapı" gibi geçerli kanıtlar gösterebilmişlerdir. Ancak sosyal bilgiler öğrencilerinden 10'u geçerli bir kanıt ortaya koyamamıştır. Yine 
fotoğraftaki mekâna dair tahminleri için kanıt göstermeleri istendiğinde tarih eğitimi öğrencilerinin 18'i geçerli bir kanıt ortaya koymuşken, sosyal bilgiler eğitim öğrencilerinin büyük çoğunluğu geçerli bir kanıt ortaya koyamamıştır. Öğretmen adayları arasında "Cami, çarpık kentleşme" gibi sadece İstanbul'a özgü olmayan olguları kullananlar veya basitçe "fikrim yok" (13 öğrenci) diyerek hiçbir kanıt göstermeyenler olmuştur.

İkinci olarak katılımcıların görselde yer alan sembolleri fark edebilme ve ne anlama geldiklerini tanımlama becerileri incelenmiştir. Bu amaçla katılımcılardan minyatürde gördükleri sembolleri tanımlamaları ve açıklamaları istenmiştir. Öğretmen adayları "bayrak, sancak, otağ, kilise, camii, hilal, haç, ezan" gibi simgeleri fark edip tanımlamışlardır. Ancak minyatürdeki en önemli simgeyi (kilisede ezan okunması - ki bu simge anlatılan olayın doğru tanımlanması için gereklidir) 48 katıımcı arasından sadece biri fark edebilmiş ve "Ezan okunması kalenin alındığını simgeler" şeklinde açıklamıştır.

Üçüncü ve son olarak katılımcıların görseldeki yazılı veya görsel mesajlardan yola çıkarak görselin kim tarafından hangi amaçla hazırlandığını belirleyebilme becerileri incelenmiştir. Bu amaçla katılımcılara üzerinde yazılı ipucu olan kolay bir görev verilmiş ve posterin kim tarafından hangi amaçla yapıldığını ortaya koymaları istenmiştir. Poster üzerindeki "Amerikan savaş tahvilleri alın." mesajına rağmen tarih eğitimi öğrencilerinden 14'ü, sosyal bilgiler eğitim öğrencilerinden ise sadece 6'sı posterin Amerikalılar tarafından yapıldığını ortaya koyabilmiştir.

Posterin yapılış amacını belirleme konusunda ise yine posterde verilen Alman figürü katıımcı öğrenciler tarafından Hun (dolaylı olarak Türk) askeri ile karıştırımasının olumsuz sonuçları gözlemlenmiştir. Öğrencilerin bu soruya verdikleri cevaplarda bir yığılma olmamış öğrenciler aşağıdaki örnekte de görülebileceği gibi çok farklı ve gerçekten uzak amaçlar ortaya koymuşlardır:

TE5 - "Zalim Türklerin Dünya barışına musallat olduğu, eğer durdurulmazlarsa kadın-çocuk öldürmeye devam edecekleri ve Amerika'nın bu barbarlara dur diyerek barış meleği olduğu anlatılmaktadır. Ayrıca Amerika'nın bunları yapabilmesi için de ekonomik olarak desteklenmesi gerektiği anlatımaktadır."

TE2 - "ABD tarafından Osmanlıya karşı kamuoyunda bir baskı uyandırmak amacıyla hazırlanmıştır. Osmanlıyı baskıcı, eziyet eden bir millet olarak 
göstermek istenmiş. Böylece Avrupalı devletlerin ABD'ye yardım etmesi ön görülmüştür."

Daha önce bahsedildiği üzere birçok öğrenci posterde kullanılan yazılı mesajı yanlış değerlendirerek posterdeki kişileri, zamanı ve olayı tanımlamada hata yapmışlardır. Bu durum Panofsky'nin (1939: Akt. Burke, 2001: 35-36) görseli doğru analiz için üretildiği dönem ve bölgenin sosyo-kültürel şartlarının bilenmesi gerektiği görüşünü doğrulamaktadır. Öğretmen adayları I. ve II. Dünya Savaşı yıllarında Hun kelimesinin İngilizler ve Amerikalılar tarafından isim olarak değil "barbar" manasında bir sıfat olarak Almanları tanımlamak amacıyla kullanıldığını bilmemektedir. Yukarıdaki alıntılarda görüleceği üzere bazı öğrenciler görseldeki anlatımdan yola çıkarak karşı tarafın "barbar veya zalim" olarak nitelendirildiğini fark etmiş ancak bu yakıştırmanın kimi kastettiğini doğru olarak ortaya koyamamıştır. Tabi bu hatayı sadece bilgi eksikliği ile açıklamak yanlış olur çünkü posterde tasvir edilen askerler gerek kıyafetleri, gerekse taşıdıkları simge ve silahları ile Hunları veya Türkleri çağrıştırmadığı halde kötü propagandası yapılan tarafın Hunlar veya Türkler olduğunu farz etmek aynı zamanda mantıksal çıkarım hatasıdır.

\section{Değerlendirme Düzeyi}

$\mathrm{Bu}$ düzeyde ilk olarak katılımcıların görselde verilen bilgi ve mesajı diğer kaynaklarla karşılaştırarak bir değerlendirme yapma varsa çelişkileri ortaya koyma becerileri hedeflenmektedir. 1920'li yıllara ait fotoğraf uygulamasında fotoğrafta açıkça görülebilecek buharlı vapurlara rağmen görselin tarihinin "14-15. yy." olarak tanımlanması, poster uygulamasında askerin elinde bulunan tüfeğe rağmen poster tarihinin henüz tüfeğin icat edilmediği "375, Hunlar dönemi veya Islamiyet’ten önceki Türk tarihi dönemi" şeklinde tanımlanması, Osmanlı askerlerinin I. Dünya Savaşında kullandığı kıyafetler birçok ders kitabında yer aldığı halde poster uygulamasında yer alan Alman askerinin "Türk veya Osmanlı askeri" olarak tanımlanması öğretmen adaylarının farklı kaynakları kullanarak değerlendirme yapma, görselde verilen bilgi ve mesajı diğer kaynaklarla karşılaştırma hususunda yeterli olmadıklarını ortaya koymaktadır.

Araştırmamızda katıımcıların kendilerine verilen görselleri mevcut bilgileri ışığında analiz etmesi hedeflenmiş bu nedenle gerek veri toplama aracında yazılı 
olarak gerekse araştırmacı tarafından sözlü olarak görsellerin künye ve detay bilgisi verilmemiştir. Buradaki amaç doğru ve güvenilir görsel analizi için ihtiyaç duyulan veriler konusunda katılımcıların farkındalık düzeyi ortaya koymaktır. Eksik bilgilerin farkında olmadan yapılacak bir görsel analizi tahminlerle oluşturulmuş bir yorumdan öteye geçemeyecektir. Katılımcılar poster ve minyatür uygulamasında daha doğru bir analiz için intiyaç duydukları bilgileri ifade etmişlerdir. Tablo 3'te ölçekte kullanılan posterin analizi için katılımcıların ihtiyaç duydukları ilave bilgilerin listesi yer almaktadır.

Tablo 3

Görseli Doğru Analiz için Katılımcıların İhtiyaç Duyduklarını Belirttikleri İlave Bilgiler

\begin{tabular}{|c|c|c|c|}
\hline \multirow{2}{*}{$\begin{array}{l}\text { Tarih Eğitimi } \\
\text { Cevaplar }\end{array}$} & \multicolumn{3}{|c|}{ Sosyal Bilgiler Eğitimi } \\
\hline & $\mathbf{F}$ & Cevaplar & $\mathbf{F}$ \\
\hline Savaşın geçtiği dönem hakkında bilgi & 7 & Yapılış tarihi & 7 \\
\hline Kim tarafından ne zaman yapıldığı & 4 & Yapılış amacı & 4 \\
\hline Daha iyi (detaylı) bir kopya & 3 & Fikrim yok & 4 \\
\hline Fikrim yok & 3 & Daha açık, anlaşılır resimler & 3 \\
\hline $\begin{array}{l}\text { 1. Dünya Savaşındaki devletlerin durumu } \\
\text { hakkında bilgi }\end{array}$ & 2 & Kim tarafından yapıldığı & 2 \\
\hline Tahvillerin ekonomik kalkınmadaki yeri & 1 & Daha çok bilgiye & 1 \\
\hline $\begin{array}{l}\text { Türk askerinin neden böyle bir davranışta } \\
\text { bulunduğu }\end{array}$ & 1 & $\begin{array}{l}\text { 2. Dünya savaşı sırasındaki Dünya } \\
\text { olayları hakkında bilgi }\end{array}$ & 1 \\
\hline $\begin{array}{l}\text { Amerikan bağımsızlık savaşı hakkında } \\
\text { bilgi }\end{array}$ & 1 & $\begin{array}{l}\text { Posteri çizen kişinin karakteri ve } \\
\text { uyruğu }\end{array}$ & 1 \\
\hline & & Bilimsel bilgilere & 1 \\
\hline
\end{tabular}

Posterin kim tarafından, ne zaman, ne amaçla yapıldığının bilinmesi doğru ve güvenilir analiz için önemlidir. Katılımcılar talep ettikleri ilave bilgiler ile bu konudaki farkındalık düzeylerini ortaya koymuşlardır. Ancak birçoğu posterde tasvir edilen askerleri yanlış tanımladığı halde hiçbir katılımcının "askerlerin uyruğu" hakkında ilave bilgi talebinde bulunmaması, metinde geçen "Hun" kelimesi ile tam olarak ne kastedildiğini sormaması veya toplamda 7 öğrencinin görseli açıklamak için gerekli bilgiler konusunda "fikrinin olmadığını" belirtmesi manidardır.

Bu bölümde son olarak öğretmen adaylarına fotoğraf uygulamasında kullanılan karşılaştırmalı fotoğrafları tarih derslerinde hangi amaçla kullanabilecekleri sorulmuştur. Tarih eğitim öğrencileri aldıkları eğitimden dolayı kavramlara daha hâkim olduklarından bu fotoğrafları "değişim ve süreklilik" kavramlarını anlatma, "karşılaştırma, somutlaştırma" amaçlarıyla kullanabileceklerini belirtmişlerdir. Sosyal bilgiler eğitimi öğrencileri ise yine "karşılaştırma, somutlaştırma" amaçlarıyla 
kullanabileceklerini belirtmişlerdir. SB4 kodlu sosyal bilgiler eğitim öğrencisi bu fotoğrafları kullanmanın; "Dönemin yaşamı, günlük hayatı ve teknolojisi gibi birçok olguyu anlatmada" faydalı olabileceğini belirtmiştir. Diğer taraftan bu konuda olumsuz görüş belirtenler de vardır:

SB3 - "Benim gözüme çarpan tek şey araçlar ve giyilen kıyafetler. O yüzden tarih dersi için çok da faydalı olacağını düşünmüyorum."

\section{Sonuç}

Öğretmen adaylarının tarihi görselleri analiz düzeylerini incelediğimiz bu araştırma sonucunda katııımcıların çoğunun:

- Tarihi görselleri analiz ederken tanımlama düzeyindeki görevlerde dahi zorlandıkları,

- Kavrama ve değerlendirme düzeylerinde hatalı değerlendirme oranlarının daha da arttığı,

- Görseller hakkında derinlemesine ve detaylı analizler yapamadıkları, genellikle kısa ifadeler ve açıklamalar kullandıkları,

- Diğer toplumlara ait görsellerde tarih ve sosyo-kültürel bilgi düzeyleri yeterli olmadığı için önemli sorunlar yaşadıkları,

- Görsellerde kullanılan simgeler hakkında yeterli bilgiye sahip olmadıkları,

- Mantıksal hatalar yaptıkları,

- Akademik bir tavır sergileyemeyerek kaynağa duygusal bir bakış açısı ile yani taraflı bir şekilde yaklaştıkları,

- Bir görseli analiz için hangi künye ve detay bilgisine ihtiyaç duyulduğunu bilmedikleri, ve netice olarak sergiledikleri görsel analiz becerilerinin aldıkları eğitime kıyasla yeterli olmadığı belirlenmiştir.

Araştırma sonuçları bu alanda yapılmış benzer araştırmalarla tutarlıık göstermektedir. Jaffe (2006) tarih alanında eğitim gören üniversite öğrencileriyle yaptığı araştırmasında öğrencilerin görselleri okumada zorlandığı, görselle ilgili sorulara tarihsel bağlamdan uzak çok kısa yorumlar yaptıklarını ortaya koymuştur. Jaffe'ye (2006) göre öğrencilerin gerçekleştirdikleri görsel analizler "basit duygusal 
yorumlamalardan öteye geçmemekte çünkü öğrenciler gerek bilgi ve gerekse beceri eksikliklerinden dolayı sadece önlerinde duran görsele bakarak bir yorum geliştirmeye çalışmaktadırlar."

Ortaya çıkan bu tabloda ülkemizde bilgi odaklı eğitimin hala geniş çapta etkin olmasının, öğrencilerde tarihsel düşünme ve araştırma becerilerini geliştirmeye yönelik çabanın azlığının, öğrencilerin pasif olduğu eğitim yöntemlerinin kullanılmasının ve eğitimin tüm kademelerinde (özellikle üniversite seviyesinde) görsellerin yanlış kullanımasının yani görsel analiz etkinliklerine yeterince yer verilmemesiniz etkisi büyüktür. Öğretmenler tarih derslerinde görselleri bir bilgi kaynağı olmaktan ziyade yüzeysel ve öğrenciler için pasif bir şekilde (Waters ve Russell, 2013: 13) sunumu zenginleştirme, anlatılanları destekleme aracı olarak kullanmaktadırlar. Görselle ilgili yapılan etkinliklerde öğrencilerden sadece görsele bakmaları veya görsel hakkında yüzeysel sorulara cevap vermeleri istenmekte, görseli derinlemesine incelemeleri, değerlendirmeleri, yorumlamaları istenmemektedir.

Oysa Fatih Projesi sonrası okullarımıza sağlanan akıllı tahta gibi BiT imkânları sayesinde farklı görsellere ulaşma ve bu görselleri sınıfın değerlendirmesine sunma çok daha kolay hale gelmiştir. BiT teknolojilerindeki bu gelişme tarih kaynaklarına ulaşmayı kolaylaştıran sanal arşivler ve görsel kullanım konusunda üst düzey beceriler geliştirmiş öğretmenlerle desteklendiğinde tarihi bilginin aktarımında sözlü-yazııı anlatımın hâkimiyeti kırılabilir. Sözlü-yazııı ve görsel anlatımı kaynaştıran bir yaklaşım hem öğrencileri bilginin pasif alıcıları durumundan çıkarıp tarih derslerini onlar için daha zevkli hale getirecek hem de öğrencilerin tarihsel düşünme, tarihsel araştırma, eleştirel düşünme ve görsel analiz becerilerini geliştirecektir. Eleştirel düşünme ve görsel analiz becerileri günümüz dünyasında bir nevi görsel kuşatma altında kalmış öğrencileri yanıltıcı ve yönlendirici görsel saldırılara karşı daha dirençli hale getirecektir.

Araştırma bulgularına göre tarih derslerinde öğrencilerin tarihsel düşünme, tarihsel araştırma ve görsel analiz becerilerini geliştirmeyi hedefleyen tarihi görsel kullanımı için öğretmenlerin dikkat etmesi gereken hususları şöyle sıralayabiliriz:

- Öğrencilerin tarihi görselleri yüzeysel ve kısa ifadelerde değerlendirmeleri eğitim hayatlarında yeterli miktarda görsel analiz aktiviteleri yapmadıklarının bir göstergesidir. Bu nedenle tarih öğretmenleri derslerine sözlü-yazılı 
anlatımı destekleyici görsel kullanım yerine daha çok görsel analiz aktivitelerine yer vermelidir.

- Öğrencilerin kullanılan görsellerdeki bazı önemli detayları gözden kaçırmaları görseller üzerinde yeterince vakit harcamadıklarının göstergesidir. Öğrencilerin görseller üzerinde daha çok vakit harcamalarını temin için bir derste çok sayıda görsel kullanmak yerine iyi seçilmiş bir ya da iki görsel kullanımı tercih edilmelidir. Öğrenciler görsel kaynak üzerinde ne kadar çok zaman harcarlarsa o kadar çok detay ve ayrıntıyı fark edeceklerdir.

- Biz araştırmamızda katıımcıları yönlendirmemek ve görsele yoğunlaşmalarını sağlamak amacıyla görseller için tanımlayıcı bir başlık veya altyazı kullanmadık. Bu durum öğrencilerin görsellerdeki zamanı, mekânı, kişileri ve mesajı analiz etmesini güçleştirdi. Ders kitapları ve derslerde kullanılacak görseller için kullanılan başıı ve altyazı ve sözlü açıklamaların özenle yapılması öğrencilerin görseli doğru okuması ve mesajı doğru anlamasını kolaylaştıracaktır.

- Doğru ve güvenilir bir görsel analizi için multi-disipliner bakış açısı, imgebilim ve simgebilim gereklidir. Öğretmen adaylarının bu alanlarda eğitim görmesi yani bir sanat tarihçisi veya sanat eleştirmeni gibi yetiştirilmesi beklenemez. Ancak Eğitim Fakültelerinde bu alanda yoğunlaşmış akademisyenler tarafından "Görsel Analiz" veya "Görsel Okuryazarlık" derslerinin verilmesi öğretmenlerin bu alandaki açığını kapatacaktır. Halen çalışmakta olan öğretmenler ise yapacakları okumalar ve araştırmalar ile bu alanlarda kendilerini yetiştirmeli ve sınıfta kullanacakları görselleri önce kendileri derinlemesine incelemelidir. Bu sayede görsel analiz aktivitesi sırasında öğrencileri verdikleri bilgiler ve ipuçları ile doğru yönlendirebilirler.

Son olarak ülkemizde görsel kaynak analiz etkinliklerinde öğretmenlere yardımcı olacak kütüphane ve dijital arşivlere büyük bir intiyaç duyulmaktadır. Araştırmamız sırasında yurtdışında faaliyet gösteren kütüphane ve dijital arşivlerin öğretmenlere görsel kaynaklar, örnek çalışma yaprakları, etkinlik örnekleri ve ders planları temin ettikleri görülmüştür. Bunlardan Amerikan Kongre Kütüphanesi, koleksiyonunda bulunan 14 milyon görsel kaynağı yukarıda sayılan etkinlik örnekleri ve çalışma yaprakları ile birlikte öğretmenlerin kullanımına sunmakla kalmamış tarih derslerinde 
bu görsellerin nasıl kullanılabileceği ve görsellerin nasıl analiz edilebileceği konusunda bir rehber yayınlamıştır (Library of Congress, t.y.).

\section{Kaynakça}

Alpan, G. (2013). Görsel okuryazarlık eğitiminin öğretmen adaylarının problem çözme yaklaşımlarına etkisi: Gazi Üniversitesi örneği. Ahi Evran Üniversitesi Kırşehir Eğitim Fakültesi Dergisi, 14(3), ss.111-130.

Ata, B. (2002). Müzelerde ve tarihi mekânlarda tarih öğretimi: Tarih öğretmenlerinin müze eğitimine ilişkin görüşleri. Doktora Tezi, Gazi Üniversitesi Eğitim Bilimleri Enstitüsü, Ankara.

Bell-Russel, D. (2011). Beyond typescript and photographs: Using primary sources in different formats. Teaching with Primary Sources Quarterly, Primary Source Formats, 4(2), Fall 2011, ss.2-7.

Bleed, R. (2005). Visual literacy in higher education. Educause Learning Initiative Explorations, August 2005, ss. 1-11. Erişim: //net.educause.edu/ir/library/pdf/eli4001.pdf

Brown, J. S. (2000). Growing up digital: The Web and a new learning ecology. Change, March/April 2000, ss.10-20.

Burke, P. (2001). Eyewitnessing: the uses of images as historical evidence. Londra: Reaktion Books.

Craver, K.W. (1999). Using internet primary sources to teach critical thinking skills in history. London: Greenwood.

Coventry, M., Felton, P., Jaffee, D., O"Leary, C. \& Weis, T. with McGowan, S. (2006). Ways of seeing: Evidence and learning in the history classroom. Journal of American History, 30(6), ss.1371-1377.

Demircioğlu, İ.H. (2007). Tarih öğretiminde öğrenci merkezli yaklaşımlar. Ankara: Anı. Howells, R. \& Matson, R. (2009). Using visual evidence. Berkshire: Open University. 
İsman, A. (2005). Öğretim teknolojileri ve materyal geliştirme. Ankara: Pegem.

Jaffe, D. (2006). Thinking visually as historians: incorporating visual methods. Journal of American History. Erişim: http: //www.journalofamericanhistory.org/textbooks/2006/jaffee.html

Kıııç, A., Seven, S. (2004). Konu Alanı Ders Kitabı Incelemesi. Ankara: Pegem.

Mahir, B. (2012). Osmanlı minyatür sanatı. 1. Baskı, İstanbul: Kabalcı.

Merriam, S. B. (1998). Qualitative research and case study applications in education. San Francisco: Jossey-Bass.

Mitchell, W. J. T. (1994). Picture theory: Essays on verbal and visual representation. Chicago: University of Chicago.

Levy, F., \& Murnane, R. (2004). The new division of labor: How computers are creating the next job market. Princeton: Princeton University.

Library of Congress (t.y.) Analyzing primary sources: Photograhs and prints tutorial. http://www.loc.gov/teachers/professionaldevelopment/selfdirected/analyzingpri marysources/index.html, Erişim: 14.09.2015.

Oblinger, D. (2003). Boomers \& gen-xers millenials: Understanding new students. Educause, July/August 2003, ss.37-47.

Özmen, H. (2005). Öğretim teknolojileri ve materyal geliştirme. N. Yiğit (Ed.) Öğretim Araç Gereçlerinin Teorik Temelleri, Trabzon: Derya Kitabevi, ss.71-98.

Pegler-Gordon, A. (2006). Seeing images in history. Perspectives on History, February 2006, 44, ss.28-31.

Sezer, A. (2006). Hayat bilgisi ve sosyal bilgiler öğretim teknolojileri ve materyalleri. A. Tanrı̈ğen (Edt) Hayat Bilgisi ve Sosyal Bilgiler Öğretimi, İstanbul: Lisans.

Smirnova, E. I., Romanov, P. (2010). Visual sources in teaching history and gender in social work, http: //www.hse.ru/data/2010/03/06/1231505380/SocialWork_larskaia Smirnova_Romanov.pdf , adresinden 18.03.2012'de alınmıştır.

Stradling, R. (2003). 20. Yüzyıl Avrupa tarihi nasıl öğretilmeli? İstanbul: Türkiye Ekonomik ve Toplumsal Tarih Vakfı. 
Şimşek, A. (2014). Tarih öğretiminde basılı görsellerin kullanımı. İ.H. Demirciğolu ve İ. Turan (Ed.) Tarih Öğretiminde Öğretim Teknolojileri ve Materyal Tasarımı. Ankara: Pegem.

Tally, B. \& Goldenberg, L.B. (2005). Fostering historical thinking with digitized primary sources. Journal of Research on Technology in Education, ss-1-21.

Uşun, S. (2012). Öğretim teknolojileri ve materyal tasarımı. Ankara: Nobel.

Yıldırım, A., Şimşek A. (2011), Sosyal Bilimlerde Nitel Araştırma Yöntemleri, 8. Baskı, Ankara: Seçkin.

Yin, R.K. (2003). Case study research: Design and methods. California: Sage.

Waters, S. \& Russell, W.B. (2013). Digital visual literacy in the social studies classroom. In W.B. Russell (Ed.), Digital Social Studies. Charlotte: Information Age, ss.7-20.

Web-1: http://www.ekopangea.com/wp-content/uploads/2015/05/galatakoprusu.jpg

Web-2: http://www.gursanteknik.com//resimler/sayfalar/album resim/3788072bc807037.png

Web-3: http://www. allposters.com/-sp/Halt-the-Hun-Buy-US-Government-Bonds-

Third-Liberty-Loan-War-Propaganda-Art-Print-Poster-Posters i8841935 .htm

Wineburg, S. S. (1991). Historical problem solving: a study of cognitive processes used in the evaluation of documentary and pictorial evidence. Journal of Educational Psychology, V. 83, ss.73-87. 


\section{Extended Summary}

\section{Purpose}

Helping students develop visual analysis skills is necessary not only in terms of comprehension and achievement levels, but also important for the development of lifelong learning skills. A person who is good in visual analysis can easily understand the diversity of actions, objects and symbols he/she witnesses in daily life and interpret them more correctly (Alpan, 2008, s.76-77). The most important element in the development of visual analysis skills of students are the teachers. The proper usage of the visuals in history lessons by teachers will have a positive impact on students' visual analysis and visual literacy skills. Therefor the aim of this research is to determine History and Social Studies teacher candidates' level of visual analysis skills

\section{Method}

In this study a qualitative case study research method was applied. Merriam (1998, p.27) described qualitative case study as description and analysis of an instance, phenomenon or social unit in an intensive and holistic manner. An embedded single-case design was used in this qualitative case study. An embedded case study is a case study containing more than one sub-unit of analysis (Yin, 2003, p.39). Three sub-skills level (identification, comprehension, and evaluation) has been determined a visual analysis skills and teacher candidates were assessed based on these three levels.

The senior students from two departments, History Education and Social Studies Education, at Atatürk University, Kazım Karabekir Education Faculty were set as study population for this research. Participants were determined on a voluntary basis and 23 senior students from History Department and 25 senior students from Social Studies Education department, total 48 teacher candidates were volunteered for this study.

\section{Data Collection Tool}

Required data for this study was gathered by using "visual analysis levels" worksheet prepared by the researchers. The worksheet contains three most common visual formats for history lessons (photograph, poster and miniature) followed by 6 
open-ended questions (total 18 open-ended questions). The questions were determined in the light of similar studies (especially Şimşek, 2014; Demircioğlu, 2007; and Straddling 2003).

Different sub-levels were determined for visual analysis skills in the literature. Panofsky (1939 Cited in Burke, 2001: 35-36) has determined three levels for visual analysis: a) Pre-iconographic analysis, B) Iconographic analysis, c) Iconological analysis. Library of Congress has also set three sub-level for visual analysis: "Observation, Reflection, and Questioning" (Library of Congress, n.d.). In this study three sub-skill levels were determined under visual analysis skills. These sub-skill levels and their extent can be seen in Table 1.

Table 1

Visual Analysis Levels and Their Extent

\begin{tabular}{|c|c|}
\hline Level & Extent \\
\hline Description & $\begin{array}{l}\text { Describing or predicting visual's type (drawing, poster, cartoon, } \\
\text { photograph, painting, gravure, miniatüre etc.), artist, production } \\
\text { date, time, place, people, peoples relations, costumes, buildings, } \\
\text { tools, geography, event or activity. }\end{array}$ \\
\hline Comprehend & $\begin{array}{l}\text { - Showing evidence (on the visual) for his/her predictions } \\
\text { - Identifying the event or activity } \\
\text { - Defining covered or uncovered symbols } \\
\text { - Defining purpose of the visual } \\
\text { - Defining target audience } \\
\text { - Defining covered or uncovered messages }\end{array}$ \\
\hline Evaluation & $\begin{array}{l}\text { - } \text { Comparing the visual with other historical resources } \\
\text { - Evaluating reliability of the information or message given by } \\
\text { the visual } \\
\text { - Defining other evidence or information needed for better } \\
\text { analysis of the visual. }\end{array}$ \\
\hline
\end{tabular}

\section{Results}

The results of the study will be summarized in in this section based on sub-skill levels.

Description Level

At this level teacher candidates' skills of describing visual's type, artist, people, people's relations, costumes, buildings, tools, geography, event or activity, and predicting time and place has been targeted. Teacher candidates participated in this 
study had no difficulty in describing people, tools, buildings or predicting place and time on the image related to Turkish history. However when we make the task somewhat difficult and require them to analyze a poster produced by different society this situation has changed. They were able to state that poster showing two soldiers, a woman and her child but many of them mistakenly answered their country of origin. They did so because they misinterpreted the written message on the poster (Halt the Hun! Buy U.S. Government Bonds) and they have limited knowledge on clothes, weapons and symbols belongs to other societies.

\section{Comprehension Level}

At this level teacher candidates' skills of showing evidence, identifying covered or uncovered symbols, and identifying producers and purpose of the visual has been targeted. Most of the teacher candidates were able to show reasonable evidences for their predictions of time and place, and recognize symbols. However, among the 48 participants only one of them recognized the most important symbol in miniature (a Muslim calling for prayer on the church - which is required to describe event) and explained it as "Call to prayer symbolizes that the castle was taken." When it comes to identifying the producer and purpose of the image despite the written message on the poster "Buy U.S. Government Bonds" only 20 (out of 48) students stated that it was produced by Americans, and most of them identified the purpose of the poster falsely due to the phrase "Hun" written on the tittle.

\section{Evaluation Level}

At this level teacher candidates' skills of evaluating given information and message by comparing visual with other resources has been targeted. Despite the steamboats that can be clearly seen in the 1920's photo some candidates date this photo to "14th-15th century," again despite the soldier holding a rifle on the poster some candidates date the poster to " $375 \mathrm{AD}$, Huns period or before İslam (6th century) period, and lastly although Ottoman soldiers clothing takes place in history textbooks some candidates described German soldier as "Turk or Ottoman soldier." All these false point of views reveals that they are inadequate in comparing visual with other resources.

Participants were also asked to define other evidence or information needed for better analysis of given visuals. Knowing the pursose, date and producer of the visual 
is critical for accurate and reliable analysis. Participants have demonstrated their awareness on this issue. However, despite many of them misidentified soldiers on the poster no participant specified requirement for "soldiers nationality" as needed information, or no participant request the meaning or what is meant by the word "Hun", and 7 participant reported that they "have no idea" on what evidence or information is needed for better analysis.

\section{Conclusion}

The results of the study reveal that many History and Social Studies teacher candidates:

- Had difficulties in visual analysis even at description level simple tasks, and their erroneous assessment rate levels increased further at comprehension and evaluation levels,

- Fail to do in-depth and detailed analysis,

- Use short phrases and explanations in their analysis,

- Face serious problems analyzing visuals belongs to other societies since they have limited socio-culturel knowledge about them,

- Do not have enough information on the symbols used in the visuals

- Make logical errors,

- Failed to demonstrate academic attitude, and approach source with biased and sentimental point of view,

- Failed to define other evidence or information needed for better analysis of given visuals,

- To sum compared to the training they receive they exhibit insufficient level of visual analysis skills. 